\title{
EUROPEAN FRAMEWORK STANDARDS FOR STUDY PROGRAMS IN FOOD SCIENCE AND ENGINEERING
}

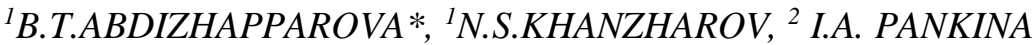

('M.Auezov South Kazakhstan University, The Republic of Kazakhstan, 160012, Shyment City, Tauke khan avenue, 5 ,

${ }^{2}$ Peter the Great Saint-Petersburg Polytechnic University, Russia, 195251, St.Petersburg, Polytechnicheskaya, 29)

Corresponding author e-mail: b.abdizhapparova@ auezov.edu.kz*

The role of European documents in the development of learning outcomes is described in the paper. In addition to the main European documents describing the qualification level of graduates, the sectoral frameworks provide a benchmark for learning outcomes in the profile of the program. Compliance with the framework standard is the foundation for a study program to receive a quality label. As an example, the EQASFood and EUR-ACE $®$ standards for study programs in the field of food science and engineering are considered. The focus on the framework standards ensure transparency and harmonization of study programs with European best practice.

Keywords: framework, European, food, science, engineering, standards, learning outcomes.

\section{ТАҒАМ ӨНІМДЕРІ ИНЖЕНЕРИЯСЫ МЕН ҒЫЛЫМ САЛАСЫНДАҒЫ БІЛІМ БЕРУ БАҒДАРЛАМАЛАРЫ ҮШІН ЕУРОПАЛЫҚ НЕГІЗДЕМЕЛІК СТАНДАРТТАР}

\section{${ }^{1}$ Б.Т. АБДИЖАППАРОВА $*{ }^{1}$ H.С. ХАНЖАРОВ, ${ }^{2}$ И.А. ПАНКИНА}

(1М.Әуезов атындағы Оңтүстік Қазақстан университеті, Қазақстан, 160012, Шымкент к., Тәуке хан даңғ., 5

${ }^{2}$ Ұлы Петр атындағы Санкт-Петербург политехникалық университеті, РФ, 195251, СПб, ул. Политехническая, 29)

Автор-корреспонденттің электрондық поштасы: b.abdizhapparova@ auezov.edu.kz*

Мақалада Еуропалық құжаттардың оқыту нәтижелерін құрастырудавы рөлі қарастырылады. Түлектердің біліктілік деңгейін сипаттайтын негізгі еуропалық құжаттардан басқа, салалық негіздемелік стандарттары білім беру баддарламасының профиліне сәйкес оқыту нәтижелеріне багдар береді. Негіздемелік стандартқа сәйкестік - білім беру багдарламасының сапа белгісін алуы үшін негіз болып табылады. Мысал ретінде тавам өнімдері инженериясы жене вылым саласындавы білім беру бавдарламаларына арналzан EQAS-Foоd және EUR-ACE® стандарттары қарастырылган. Негіздемелік стандарттарына базыттау білім беру баддарламаларын ашықтызын қамтамасыздандырады және еуропалық озық тәжірибесімен үйлестіруге мүмкіндік береді.

Негізгі сөздер шеңбер, тамақ өнімдері, ғылым, инженерия, стандарт, оқыту нәтижелері.

\section{ЕВРОПЕЙСКИЕ РАМОЧНЫЕ СТАНДАРТЫ ДЛЯ ОБРАЗОВАТЕЛЬНЫХ ПРОГРАММ В ОБЛАСТИ НАУКИ И ИНЖЕНЕРИИ ПИЩЕВЫХ ПРОДУКТОВ}

\section{${ }^{1}$ Б.Т. АБДИЖАППАРОВА ${ }^{*},{ }^{1}$ H.С. ХАНЖАРОВ,${ }^{2}$ И.А. ПАНКИНА}

('Южно-Казахстанский университет им. М.Ауэзова, Казахстан, 160012, г. Шымкент, пр. Тауке хана, 5,

${ }^{2}$ Санкт-Петербургский политехнический университет Петра Великого, г.Санкт-Петербург, РФ, 195251, СПб, ул. Политехническая, 29

Электронная почта автора-корреспондента: b.abdizhapparova@ auezov.edu.kz* 
В статье рассматривается роль европейских документов в разработке результатов обучения. Поимимо основных европейских документов, описывающих квалификационный уровень выпусников, ориентир на результаты обучения по профилю программы оказывают секторные рамки. Соотстветствие рамочному стандарту является основой для получения образовательной программой знака качества. В качестве примера рассматриваются стандарты EQAS-Food и EUR-ACE® для образовательных программ в области науки и инженерии пищевых продуктах. Фокус на обоих рамочных стандартах позволяет обеспечить прозрачность и гармонизированность образовательных программ с европейской лучшей практикой.

Ключевые слова рамки, европейский, пищевые продукты, наука, инженерия, стандарты, результаты обучения

\section{Introduction}

As it is known all main European documents describing qualification level of graduates such as Dublin descriptors, Qualifications Frameworks in the European Higher Education Area (QF-EHEA), European Qualifications Framework for Lifelong Learning (EQF-LLL) are based on learning outcomes [1]. The key advantage of learning outcomes is their objectivity, clarity and measurability, which contributes to transparency of study programs. Learning outcomes in European Diploma Supplement serve for identification knowledge, skills and abilities of its owner.

For institutions, the formulation of learning outcomes is one of the main stages in the development of study programs, which determines their quality and relevance. Formulation of learning outcomes is a deep and detailed effort to concretize what a student should be able to do and understand what is expected of them. They must be achieved within the time and resources of a module. In practice, learning outcomes are developed at the level of study programs, individual modules and even training sessions. A number of recommendations have been developed for the development of learning outcomes [2-4]. Kazakhstan universities also consider professional standards, industry frameworks and competencies listed in the Atlas of new professions and competencies of Kazakhstan.

Sectoral (subject-specific) frameworks provide guidance on learning outcomes related to a program profile, for example, the EURACE® (EURopean - ACcredited Engineer) engineering accreditation framework standards, developed by the European Network for Accreditation of Engineering (ENAEE) [5], ECTN recommendations for evaluating applications for Eurobachelor ${ }^{\circledR}$ and Euromaster ${ }^{\circledR}$ quality labels for study programs in chemistry and chemical engineering [6-7], EuroInf® framework standards and accreditation criteria for study programs in informatics developed by the European Quality Assurance Network for Informatics Education (EQANIE) [8], EQAS-Food standards adopted by the European ISEKI-Food Association [9] etc. As a rule, these documents use terminology that corresponds to structure of higher education created in the framework of the Bologna process.

These thematic networks are members of European Alliance for Subject-Specific and Professional Accreditation and Quality Assurance (EASPA).

It should be noted that these quality labels can be issued by accreditation agencies along with a certificate of accreditation of a study program, if they have agreements and are members of the relevant thematic networks. This practice is widely used by the German agency ASIIN. The agency is authorized to award the following professional quality seals:

-for engineering sciences: the EUR-

$\mathrm{ACE}^{\circledR}$ Label

-for chemical sciences: the Euro Label

- for computer science/business

informatics: the Euro-Inf ${ }^{\circledR}$ Label

-for food sciences: the EQAS-Food Label

-for medical sciences: the AMSE/ASIIN

seal, based on the criteria of the World

Federation of Medical Education (WFME)

In Kazakhstan, the agency in the field of engineering KazSEE and in Russia the Association for Engineering Education of Russia (AEER) are authorized to award the EUR-ACE® label.

It is a question of interest to study EURACE® and EQAS-Food standards, specializing in engineering and food sciences. The purpose of this research is identifying a role of the framework standards at the development of 
study programs in the specified area. It will be achieved by performing the following tasks:

- to study content of the standards;

- to define the difference of the offered learning outcomes for first and second cycles;

- to analyze their application for development study programs in specified area.

\section{Materials and research methods}

Objects of research are:

- EUR-ACE® standards (EURopean ACcredited Engineer), developed by European Network for Accreditation of Engineering Education (ENAEE);

- EQAS-Food standards adopted by the European ISEKI-Food Association.

Both of these standards can be applied at accreditation of study programs in food science and engineering.

Standards EUR-ACE® promote quality engineering education across Europe and beyond, so engineering graduates are fully equipped to tackle the issues in modern engineering projects [5].

EQAS-Food criteria are assigned for identification high-quality bachelor and master programs in food science and engineering [9].

EQAS-Food standards allow identifying an affinity of a study program to area of food science and technology. The standards demonstrate distinction between programs with primary focus on food science and technology, and programs with secondary role of food science and technology. First-type programs i.e. mainly oriented on food science and technology deserve the label EQAS-Food.

EUR-ACE ${ }^{\circledR}$ standards are intended to be broadly applicable and inclusive in order to apply them in all engineering branches, also to reflect the diversity of engineering diploma programs in EHEA which promote education necessary for graduates to enter in engineering profession and recognize their qualification [5].

As it mentioned in characteristics of EURACE® quality label these standards are quality assurance system for engineering programs.
As a method of research, a theoretical analysis of above-mentioned methods was chosen. It included study of structure of standards and comparison of offered learning outcomes for first and second cycles.

\section{Results and their discussion}

As other framework standards, EQAS-Food and EUR-ACE® standards contain learning outcomes. Learning outcomes for EQAS-Food standards are grouped into five subject areas:

1. Food Safety and Microbiology essential to produce safe foods; microbiology, toxicology and applied safety management belong to this group of outcomes.

2. Chemistry and analysis of food products - analysis of foods, chemical composition, physical properties and sensory characteristics of foods.

3. Food processing and engineering - how to process foods with optimized product quality and hygiene, with knowledge of the food product and of the processing plant, with adequate water and waste management.

4. Quality management and food law.

5. Generic competencies - communicative abilities, ethics and personal skills.

Essentially, these five trends characterize a profile of a program developed in area of food science and engineering. Despite on variety of implemented study programs, food technological process, as a rule, is connected with mandatory chemical and sensory analysis of raw material, semifinished products and ready products, safety issues on each technological stage, waste processing, quality management system, pollution regulation norms, packaging materials, labelling, product certification etc. Herewith, graduates should understand ethics norms and possess communicative abilities sufficiently.

These standards represent visual comparison of learning outcomes for first and second cycles; it may be analyzed with example of learning outcomes in food processing and engineering (Table 1). 
Table 1. EQAS-Food standards minimum learning outcomes in the field "Food processing and engineering" [9]

\begin{tabular}{|c|c|}
\hline (A) First cycle & (B) Second cycle \\
\hline $\begin{array}{c}\text { Identify sources of raw material, explain the } \\
\text { variability and the impact on food processing } \\
\text { operations. }\end{array}$ & $\begin{array}{c}\text { (A) + propose alternative ways of utilization of } \\
\text { lower quality raw materials. }\end{array}$ \\
\hline $\begin{array}{c}\text { Understand the fundamental concepts of mass, heat, } \\
\text { and momentum transfer required in food unit } \\
\text { operations. Calculate mass and energy balances for } \\
\text { a general food process }\end{array}$ & $\begin{array}{c}\text { Propose solutions for the practical application of } \\
\text { the fundamental concepts of mass, heat, and } \\
\text { momentum transfer in food processing }\end{array}$ \\
\hline $\begin{array}{c}\text { Explain the principles and current practices of } \\
\text { major food processing operations, and understand } \\
\text { the effect of processing parameters on product } \\
\text { quality }\end{array}$ & $\begin{array}{c}\text { (A) + Understand the principles of process control } \\
\text { and instrumentation }\end{array}$ \\
\hline $\begin{array}{c}\text { Explain characteristics and properties of packaging } \\
\text { materials for food products and identify appropriate } \\
\text { packaging systems. }\end{array}$ & $\begin{array}{c}\text { Demonstrate understanding about characteristics } \\
\text { and properties of packaging materials to select } \\
\text { appropriate packaging systems for selected } \\
\text { applications }\end{array}$ \\
\hline $\begin{array}{c}\text { Understand the basic principles and practices used } \\
\text { for cleaning and sanitation of food process } \\
\text { equipment, including the use of water, cleaning } \\
\text { chemicals and waste management. }\end{array}$ & $\begin{array}{c}\text { Understand current practices in maintenance of } \\
\text { plant hygiene through CIP and its relation to } \\
\text { GMP, the use of water in processing, and the } \\
\text { management of waste streams. }\end{array}$ \\
\hline
\end{tabular}

So, if a bachelor can define sources of raw material and explain their impact on technological operations, a master can offer alternativeways of application of law-quality raw material as well. A bachelor can explain principles and current practices of basic operations on processing foods and understand influence of processing parameters on food quality; meanwhile a master understands principles of process control and instrumentation.

It should be noted that achievement by student of any these results by a student may occur in one or several modules because EQASFood does not assume any restrictions relating program development. Programs pursuing the aim to be awarded the seal should demonstrate how they fulfill vast majority of requirements of learning outcomes in each of these five areas.

At accreditation in European association ISEKI-Food institutions should complete the
Alignment Matrix of Program Learning Outcomes to show where and how far they comply with the EQAS LO.

Learning outcomes in EUR-ACE® are grouped in eight knowledge fields both for bachelor and master programs:

- Knowledge and understanding;

- Engineering Analysis;

- Engineering Design;

- Investigations;

- Engineering Practice;

- Making Judgements;

- Communication and Team-working;

- Lifelong Learning.

It is also easy here to compare their description for both levels. As an example, table 2 provides a comparison of learning outcomes for the field "engineering analysis". 
Table 2. EUR-ACE® standards learning outcomes in the field "Engineering analysis" [5]

\begin{tabular}{|l|l|}
\hline \multicolumn{1}{|c|}{ First cycle } & \multicolumn{1}{c|}{ Second cycle } \\
\hline $\begin{array}{l}\text { Ability to analyse complex engineering products, } \\
\text { processes and systems in their field of study; to select } \\
\text { and apply relevant methods from established } \\
\text { analytical, computational and experimental methods; } \\
\text { to correctly interpret the outcomes of such analyses }\end{array}$ & $\begin{array}{l}\text { Ability to analyse new and complex engineering products, } \\
\text { processes and systems within broader or multidisciplinary } \\
\text { contexts; to select and apply the most appropriate and } \\
\text { relevant methods from established analytical, computational } \\
\text { and experimental methods or new and innovative methods; } \\
\text { to critically interpret the outcomes of such analyses }\end{array}$ \\
\hline $\begin{array}{l}\text { Ability to identify, formulate and solve engineering } \\
\text { problems in their field of study; to select and apply } \\
\text { relevant methods from established analytical, } \\
\text { computational and experimental methods; to } \\
\text { recognise the importance of non-technical -societal, } \\
\text { health and safety, environmental, economic and } \\
\text { industrial - constraints. }\end{array}$ & $\begin{array}{l}\text { Ability to identify, formulate and solve unfamiliar complex } \\
\text { engineering problems that are incompletely defined, have } \\
\text { competing specifications, may involve considerations from } \\
\text { health and safety, environmental, economic and industrial - } \\
\text { constraints; to select and apply the most appropriate and } \\
\text { relevant methods from established analytical, computational } \\
\text { and experimental methods or new and innovative methods } \\
\text { in problem solving }\end{array}$ \\
\hline \multicolumn{2}{|c|}{$\begin{array}{l}\text { Ability to conceptualise engineering products, processes } \\
\text { and systems }\end{array}$} \\
\hline $\begin{array}{l}\text { Ability to identify, formulate and solve complex problems } \\
\text { in new and emerging areas of their specialisation }\end{array}$
\end{tabular}

If a bachelor can analyze complex engineering products, processes and systems in the field of study, choose and apply suitable research methods and process investigation results, a master can work in multidisciplinary context with new products, processes and systems and choose the most appropriate new or innovative research methods and critically interpret results.

Of course, EUR-ACE® standards represent an extended characteristic of engineering study programs, meanwhile, EQAS-Food standards have only one engineering area from fives, therefore their direct comparison is not correct. It is important to understand if a study program in the field of food engineering or food program with some elements of engineering is being developed, then focus on the both standards will promote synergy impact of best European practices.

\section{Conclusion}

EQAS-Food and EUR-ACE® standards have significant role in distribution of best practices and making contribution in constant development of study programs. They correspond to QF-EHEA and EQF-LLL, can be applied as a guidance for development of programs in food science and engineering.

Focus on these standards for domestic institutions which train bachelors and masters in mentioned area will permit to:

-emphasize requirements to bachelor and master programs; -define the boundary of separation of developed programs into programs with core food profile and related ones;

-use the recommended learning outcomes on subject areas at development of study programs;

-ensure transparency and harmonization of study programs with best European practice [1].

\section{REFERENCES}

1. Abdizhapparova B.T., Khanzharov N.S. European standards EQAS-Food for educational programs in the field of food science // Innovative Scientific Research - 2021 - №3-1 (5). - PP. 97103 (in Russian)

2. Kennedy D. Writing and using learning outcomes: a practical guide / Translated by Karacharova Ye.N. - Ireland: Cork University, 2007. $-30 \mathrm{p}$

3. Walsh A., Webb M. Handbook on writing learning outcomes, Kingston University, 2002. - 448 p.

4. O'Brien J. Writing Learning Outcomes. A guide for academics. - 2007. - Limerick:University of Limerick- 129 p.

5. European Network for Accreditation of Engineering Education (ENAEE). EUR-ACE® Framework Standards and Guidelines Access mode : https://www.enaee.eu/eur-ace-system/standards-andguidelines/ Application date June 13, 2021

6. European Chemistry Thematic Network Association (ECTN). The chemistry Eurobachelor Guidelines Access mode: URL.:http://ectn.eu/wpcontent/uploads/2019/03/2-

eurobachelor_documentation-19_01.pdf (Application date: June 13, 2021) 
7. European Chemistry Thematic Network Association (ECTN). Thechemistry "Euromaster" Access mode: URL.: http://ectn.eu/wpcontent/uploads/2019/03/2-

euromaster_documentation-150101.pdf (Application date:June 13,2021)

8. European Quality Assurance Network for Informatics Education (EQANIE). Euro-Inf framework standards and accreditation criteria for informatics degree programmes Access mode:
URL.:http://eqanie.eu/wpcontent/uploads/2019/09/Euro-Inf-FrameworkStandards-and-Accreditation-Criteria-V-2016-1024.pdf (Application date: June 13,.2021)

9. ISEKI Food Association. European quality assurance for food studies programmes food science and technology Access mode: URL.: https://www.iseki-food.net/sites/isekifood.net/files/download/96/framework_doc_edit_rc 18.02.19.pdf (Application date: June 13,2021) 